\title{
Research on Independent College Students' Innovation and Entrepreneurship Education
}

\author{
Dai Rui \\ Oxbridge College, Kunming University of Science and Technology, Kunming, Yunnan, China
}

Keywords: independent college; innovation and entrepreneurship education; self-employment

\begin{abstract}
To build an innovative country, the education and cultivation of college students' innovation and entrepreneurship in the process of talent cultivation in higher education cannot be ignored. This paper analyzes the necessity of carrying out innovation and entrepreneurship education for undergraduates in independent colleges and analyzes the construction of independent entrepreneurship education model in independent colleges.
\end{abstract}

\section{Introduction}

The independent college, as a new thing in higher education, itself has a process of continuous development and continuous recognition by the people. At present, the social demands for work experience, social practice, and colleges and universities for graduation have made the employment situation of independent college students more severe. If students can start their own businesses after graduation, they can not only create new jobs, effectively relieve social employment pressure, but also innovate the concept of employment and career choice of college students. This is a "win-win" employment approach. However, for independent colleges, entrepreneurship education still lags far behind. To cultivate what kind of entrepreneurial talents and how to cultivate them, it is urgent to establish a new model and a new system in independent colleges.

\section{Necessity of Carrying out Innovation and Entrepreneurship Education in Independent Colleges}

The source characteristics of independent colleges need innovation and entrepreneurship education. Most of the students in independent colleges have good family economic conditions. Although the basics of learning and learning habits are not as good as one or two students, they are one or two more in terms of interpersonal communication skills, organizational coordination ability, and innovation ability. The students have obvious advantages. Therefore, college students who educate and train independent colleges should use their strengths to avoid weaknesses, develop the strengths of innovation, and train and cultivate their entrepreneurial skills.

Economic development promotes higher education to enter the era of innovation and entrepreneurship. From the perspective of social development, the future of the social economy increasingly requires more flexible and innovative companies and products. The importance of independent innovation and entrepreneurship for the future labor market is growing. Unremittingly conducting innovation and entrepreneurship education based on cultivating students' awareness of innovation and entrepreneurship and ability can enable the strategy of rejuvenating the country through science and education [1].

Soaring employment pressure requires innovation and entrepreneurship education to open up a new phase. At present, the number of college graduates has reached record highs, and the employment situation is very severe. In particular, independent college students, many employers explicitly stated that they would not be independent college graduates. Therefore, through the development of college students' innovation and entrepreneurship education, they have become "not only job seekers but also entrepreneurs who provide employment opportunities for others". This has become an urgent need for the times and reality. Analysis on the key points of innovation and entrepreneurial education in independent colleges. 


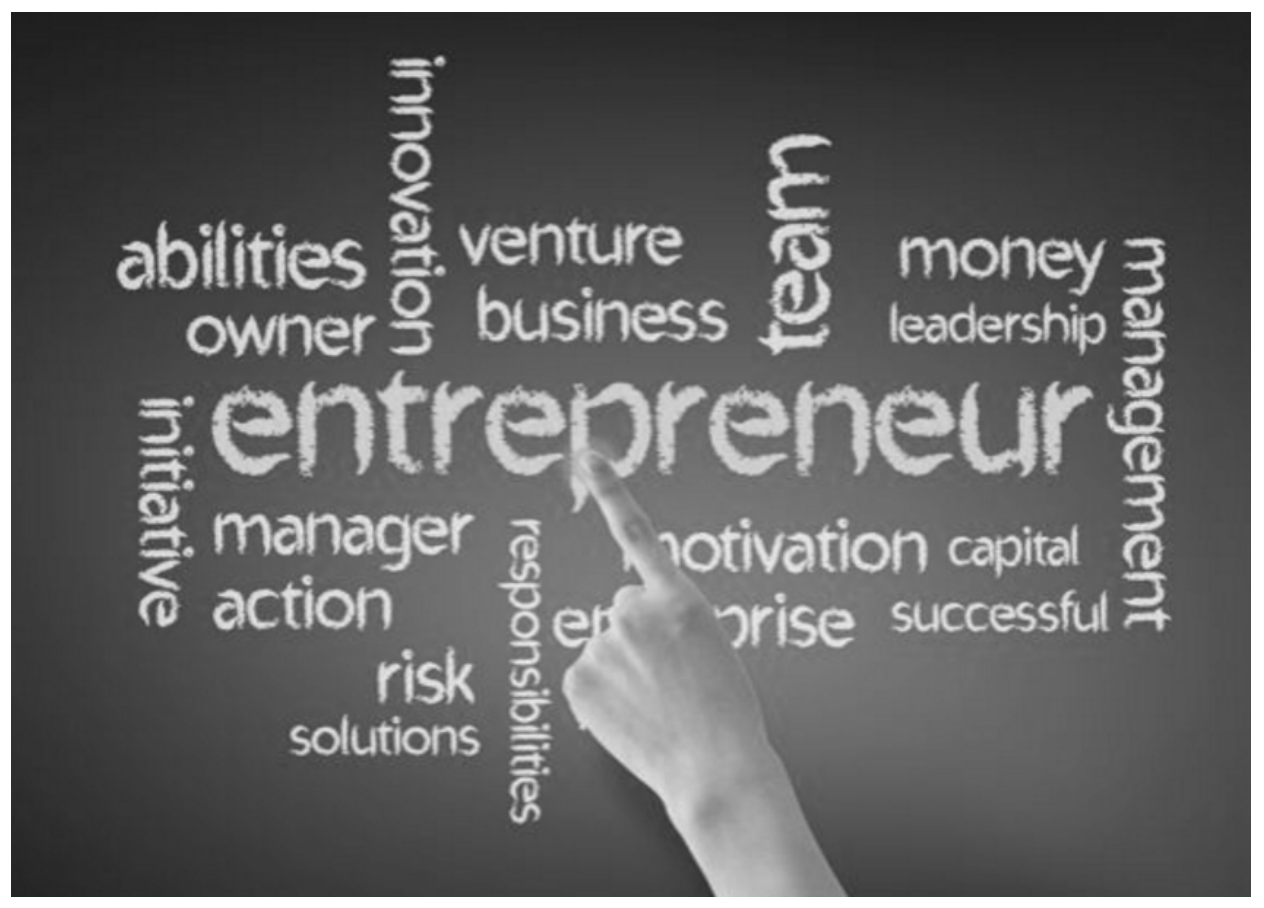

Fig. 1 key points of innovation and entrepreneurial education in independent colleges

\section{Reflections on the Construction of Innovation and Entrepreneurial Education Model in Independent Colleges}

Since the start-up of China's entrepreneurship education is still late, it is still in a state of spontaneous, decentralized, and exploration. In most universities and colleges, innovation and entrepreneurship education is not considered as a part of the mainstream education system of higher education, nor is it given in teaching management. Full attention. Therefore, to cultivate a large number of talents with innovative spirit and entrepreneurial ability, we must break the "bottleneck" that restricts China's innovation and entrepreneurship education. In response to the establishment of independent college entrepreneurship education model, we propose the following points:

\subsection{Regulating the innovation and entrepreneurship education curriculum system}

Add special innovation and entrepreneurship education courses. Independent colleges can integrate innovation and entrepreneurship education into employment guidance and internship practice classes, and conduct innovation and entrepreneurship education according to the characteristics of various disciplines, and add special innovation and entrepreneurship education courses, such as: entrepreneurial basic theory courses, entrepreneurial practice courses, and management potentials. Classes of courses, quality development courses, etc., to enrich university students' knowledge of innovation and entrepreneurship, so as to systematically understand and master the knowledge and skills related to founding and managing small businesses. The Innovation and Entrepreneurship Class strives to turn teachers into assistants who promote independent thinking among students, turn textbooks into tools for students' interest, and turn classrooms into a stage for students to develop their own potential [2].

Conduct entrepreneurship education activities in the second classroom. In the extra-curricular activities, we will carry out innovation and entrepreneurship competitions, innovation and entrepreneurship exchanges, and open innovation and entrepreneurship education lectures to carry out innovation and entrepreneurship education. We will regularly invite entrepreneurial successful people to conduct face-to-face dialogues with students to provide entrepreneurial learning and guidance.

Try to do the "Innovation and Entrepreneurship Education" minor. At present, many universities abroad have set up the "entrepreneurship" major. The opening of innovation and entrepreneurship education is conducive to comprehensively improving the level of innovation and entrepreneurship 
education in China. However, this cannot meet the needs of students who have chosen other majors and have entrepreneurial requirements. Therefore, opening the form of minors in innovation and entrepreneurship education can enable more students who are interested in innovation and entrepreneurship to receive more systematic training in entrepreneurship, and it is more in line with China's national conditions, the current status of university reforms, and the characteristics of running an independent college [3].

\subsection{Foster a new type of teachers with innovative awareness and competence}

The current teaching models are classroom lectures and case discussions. This type of "teachers speak, students listen, fill the classroom, and follow the receipts" education method cannot mobilize the students' initiative, and also suppress the students' personality development and the ability to innovate. Independent colleges must fully cultivate high-level innovative talents. It is imperative that the most important task is to cultivate a group of teachers with innovative awareness and innovative ability. Only high-level innovative teachers can cultivate students with strong innovation and entrepreneurial ability. High-level innovative teachers have the means and methods to inspire students' thinking and broaden students' thinking. They dare to transform from the traditional knowledge imparters to the students' learning leaders and the students' ability to train creative abilities. They have a strong desire for knowledge and a strong research ability in the latest theories of domestic and international frontier theories and cross-disciplines related to the subject. They are also good at applying their latest educational scientific research results to teaching. This helps Students improve their overall understanding of the development of the discipline, find breakthroughs, and innovate[4]. The formula for innovation ability is as follows.

$$
p_{i j}=x_{i j} / \sum_{i=1}^{m} x_{i j}
$$

\section{Active Promotion of Innovation and Entrepreneurship Education}

\subsection{Cooperate with labor bureau to conduct entrepreneurial guidance}

In recent years, China's governments at all levels have successively introduced policies such as tax relief and microfinance to promote employment and entrepreneurship. More and more universities are graduating with the gradual introduction of entrepreneurial policies and the gradual introduction of entrepreneurial service systems. Students achieve reemployment through self-employment or self-employment. Labor departments in various localities have carried out "one-stop" services such as entrepreneurship training, policy advice on opening up, project demonstration, and follow-up counseling to build "green channels" for graduates to start their own businesses. The independent college can use the resources of the labor department to cultivate entrepreneurial teachers in universities and provide follow-up services to students.

\subsection{Participate in business competitions at all levels to promote}

Independent colleges can organize students to participate in entrepreneurial competitions at all levels. Students participate in various professional competitions and scientific research activities, such as "Challenge Cup" Chinese college students extracurricular science and technology works contest and "enterprise plan" contest, to enhance the sense of innovation, exercise and improve the observation, thinking, imagination and hands-on ability It is very helpful. Only by creating a strong atmosphere of scientific and technological innovation among college students can more innovative talents come to the fore. Practice can best exercise and cultivate a person's talents. Only by looking, thinking, asking, remembering, testing repeatedly, repeatedly investigating, summing up, and drawing lessons from practice can one find out the true knowledge from practice.

\subsection{Form a start-up community and entrepreneurship training base}

Entrepreneurial clubs are student-centered informal organizations that focus on a group of students who are passionate about entrepreneurship and can play a role in propagating basic 
entrepreneurial knowledge. At the same time, they may also be potential candidates for further training and personal entrepreneurship. Entrepreneurial groups. Entrepreneurship training bases, which are provided by schools or cooperative companies, are used as campus "enterprise parks" and "small business incubators." Potential students can apply for a project. After the program is passed, students can set up a number of on-campus companies or conduct business within the school according to their abilities, or the school can organize a simulation company to provide a platform for students to experience entrepreneurship.

\section{Summary}

In short, independent college students' innovation and entrepreneurship education is a systematic project. It is a long-term and arduous task to improve college students' awareness of innovation and entrepreneurship, and requires common concern and concern from society, schools, families, and teachers. It is hoped that through the joint efforts of all of us, we will establish a new concept of self-employment in college students that "passion changes their destiny, creates a glorious life".

\section{References}

[1] leana Hamburg,Gabriel Vladut,Emma O'Brien. Fostering skills for digital social innovations in entrepreneurship education [J]. Balkan Region Conference on Engineering and Business Education, 2017, 3(1).

[2] Ying-Ying Ding. The constraints of innovation and entrepreneurship education for university students [J]. Journal of Interdisciplinary Mathematics, 2017, 20(6-7).

[3] R. Radharamanan,Jeng-Nan Juang. Innovation and entrepreneurship in engineering education at MUSE [J]. Journal of the Chinese Institute of Engineers, 2012, 35(1).

[4] Niccum Blake A,Sarker Arnab,Wolf Stephen J,Trowbridge Matthew J. Innovation and entrepreneurship programs in US medical education: a landscape review and thematic analysis.[J]. Medical education online, 2017, 22(1). 